\title{
Problems and Factors of Non-Completion of Promising Projects by Young Entrepreneurs: The Case of Tunisia
}

\author{
Salah Ben Hamed, Samira Boussema \\ Lab. MODEOR, University of Sfax \\ benhamad_salah@yahoo.fr
}

\begin{abstract}
Our study attempted to explore the different problems and factors of the non-completion of business projects by a representative sample of project promoters. Four factors were selected to examine the issue, which are: resources availability and ease of access to finance, lack of capital and its impact on projects, promoters' competencies and cognitive skills and their projects vision as entrepreneurs to overcome obstacles. A Principal Component Analysis (PCA) has shown that the financial factor is the main factor of the non-completion of promising projects by young project promoters.
\end{abstract}

Keywords: Entrepreneurship, funding, governance, non-completion of projects

\section{Introduction}

The downturn in the global economy has resulted in a significant slackening of the labour market. The sharp increase in unemployment has amplified interest in entrepreneurship. In recent years, research in this area has been growing responding to concerns of politicians, economists and society, since the major concern of all countries is to ensure sustainable economic development and to reduce unemployment rate. The latter is conditioned by a strong entrepreneurial activity. Although a project manager is found torn between the dream and reality to create their own business and secure a job Fayolle and Nakara (2010), the remaining challenge is to overcome the result of the entrepreneurial process and the establishment of an organization.

The theoretical framework and research problem: Entrepreneurial activity is governed by a process of organizational emergence. Many researchers showed interest in studying this phenomenon (Gartner, 1985; Greenberger and Sexton, 1988; Hernandez, 1999; Verstraete, 2001; Watkins, 1976; Learned, 1992). These studies have focused on the project's assembly phase into production until activity stabilization. This allows defining the process leading to the emergence of a new organization (Aldrich, 1999; Sharma and Christman, 1999; Verstraete, 2001; Hernandez, 2001). However, interaction between resources and business plan has been little studied. On the other hand, many researchers have focused on the study of the causes of corporate bankruptcies (Ucbasaran et al., 2010; Cope et al., 2004; Cope, 2011; Mantere et al., 2013; Michael, 2008; McKenzie 2008), and their success (Willerding et al., 2012; Hatala, 2005; Edward et al., 2004). In general, the creation of a new business is the cornerstone of Gartner modelling (1985), which focused on the birth of new organizations and especially the profile of the most successful companies. Gartner focused on the study of the entrepreneur's actions and behaviors throughout the entrepreneurial process. Entrepreneurship is seen as evolutionary in nature. The entrepreneur follows a dynamic learning process to acquire skills and knowledge so that they can overcome the obstacles to the completion and success of the project.

Similarly, we will focus on the study of the implementation phase of business projects. As most entrepreneurs face obstacles and difficulties related to creating their own businesses (Gasse, 2002; Fayolle, 2003), we therefore ask the following question: Why do some entrepreneurial projects may emerge while others do not? So many obstacles may arise when creating a business. The financing constraint is the major obstacle to the creation of new businesses (Lofstrom et al., 2013). Financing of new firms has a great importance as entrepreneurs' resources are generally limited. This latter assumption is supported by Jensen and Meckling (1976). Entrepreneurs, in the implementation phase of the project, find themselves trapped in a vicious circle of access to finance (Hellmann, 2000). Moreover, "Funding is the main request from entrepreneurs to financial institutions and support mechanisms" (Botzung, 1996). The ability of entrepreneurs to build their businesses depends primarily on their ability to obtain financial resources (Aldrich and Martinez, 2001). Innovative companies generally face implementation difficulties when it comes to meet their financial needs (Sherif, 1999). 
The concern with non-completion and failure of small businesses increases when they are not well capitalized (Cooper et al., 1994; Bates, 1997; Dunn and Holtz-Eakin, 2000; Hout and Rosen, 2000; Fairlie and Robb, 2008; Parker, 2009; Lofstrom et al., 2013). Similarly, Fazzari et al. (1988) found that newly created and small-sized businesses are more limited in external financing because they are not well known by bankers. As there is no trust relationship between them, they suffer a lack of legitimacy which heightens the problem of access to finance (Scott and Meyer, 1991; Scott, 1995), hence our hypothesis:

H1: The non-completion of business projects is conditioned by the non-availability of financial resources and barriers.

Given that access to finance is the main determinant of business projects completion (Rajan and Zingales, 1998. Aghion et al. (2007), entrepreneur's capital remains an important element that should be taken into consideration when financing businesses (Bates, 1997), although most entrepreneurs lack equity (Botzung, 1996). According to Mohnen and Rosa (2001), "Lack of capital leads to lack of external capital". In general, in most cases, the initial capital comes from financial institutions and family wealth (Bates, 1997). During firm creation phase, the entrepreneur faces difficulties of insufficient initial capital (Julien and Marchesnay, 1988). This greatly threatens the completion of business plans of potential entrepreneurs (Evans and Jovanovic, 1989). In fact, social capital or institutional capital (Yiu and Lau, 2008) forges exchange relationships with the firm's different stakeholders (Nahapiet and Ghoshal, 1998; Adler and Kwon, 2002) as it offers the possibility to have a competitive advantage (Oliver, 1997). Evans and Jovanovic (1989) and Parker (2009) found that entrepreneur wealth can stimulate entrepreneurship and promote business creation. Although it is a constraint, it is a good incentive for funding capital and facilitating bank financing of small businesses (Lofstrom et al., 2013). The share in own capital directly influences Bankers (Bates, 1991), and may cause problems with bank financing (Owualah, 1987, Baldwin and Johnson, 1996), hence our hypothesis:

H2: Availability of capital does not reassure stakeholders of the entrepreneurial process and does not favour the birth of projects.

According to Klein P-G (1999), the cost of financial resources, skills and cognitive skills are the main barriers to business creation. Casson (1995) adds that education is the main guarantor of good skills to ensure proper implementation and functioning of the project. Furthermore, Bates (1997) suggests that graduate entrepreneurs have more access to other funding. Rogers (1976) "The only trained individual is the one who has learned how to learn, how to adapt and change". For Parker and Van Praag (2006), entrepreneurs who have cognitive abilities have less risk when granted credits. They are more likely to convince bankers. This is why cognitive knowledge may overcome financial obstacles. Moreover, entrepreneur's cognitive abilities promote the passage to the entrepreneurial act. They are powerful engines that drive the entrepreneur and lead to the completion of their projects (Fayolle, 2003 and Morin, 2001). Moreover, Lichenstein et al. (2006) suggests that the birth of new firms is influenced by the anticipation of the environment and the right decision. The difficulty of drafting and understanding the content of a business plan induces entrepreneurs to consider abandoning the project. In the same vein, Alchian and Demsetz (1972) add that the imperfect knowledge of production factors contributes to the risk as it complicates implementing the entrepreneurial function. Similarly, Mises (1949) and Witt (1998) add that entrepreneurs should know how to choose the production method that works best with its organization and which minimizes costs.

Kirzner (1997) and Witt (1998b) suggest that ignorance of market conditions leads to misinterpreting the market and subsequently to a bad decision, since the entrepreneur should be a good decision maker. Furthermore, industry entrepreneurs' and engineers' skills complementary are necessary to ensure the proper development of the project. In this regard, Bayad et al. (2006) state that "The entrepreneur should develop specific skills other than technical skills". Berle and Means (1932) concluded that the role of the shareholder was reduced to the single role of providing financial resources and assuming financial risk. Charreaux (2002) focused on the cognitive influence of the dominant industrial-type shareholder that has more managerial and perceptual skills. Charreaux (2002 a and b), through the cognitive governance model, considers the company as a knowledge repository thanks to the complementarily in skills between shareholders and managers, to innovation spirit, knowledge, and the perception of new investment and value creation opportunities. The latter is achieved through good corporate governance which results in the reduction of agency conflicts and in a better monitoring (Lakhal, 2006). For Berle and Means (1932), governance problem is a problem of separation of ownership and decision-making in the company. On the other hand, Leftwich et al. (1981) showed that "The increasing presence of reinforced outside directors leads to a more effective control of managers". According to Fama and Jensen (1983), possession of a 
single individual holding the dual functions of General Manager and Chairman of the Board greatly threatens control of the company. In this case the chairman is aligned with management rather than shareholders (Forker, 1992), hence our hypothesis:

\section{H3: Cognitive skills and knowledge are the main causes of non-completion of projects.}

Witt (1998a, b) described entrepreneurship as a specific form of cognitive leadership. According to Analoui and Karami (2003), leadership is an important factor that guarantees the successful completion of business projects. Powered by the need for achievement, the entrepreneur can overcome barriers to entrepreneurship (Begley and Boyd, 1987; Stewart et al., 1999). In entrepreneurship, leadership is the ability of the entrepreneur to create visionary scenarios to assemble and mobilize different participants to achieve objectives and create value (Gupta et al., 2004). They set and pursue goals, bring together resources and perform different tasks (Callon, 1989). For the entrepreneur, leadership encourages them to step back, to reorganize their thoughts, to gain confidence, overcome obstacles, to master their doubts and clarify their vision Couteret and Audet (2008). In general, the entrepreneurial spirit is triggered by the vision of the entrepreneur. This ensures growth of entrepreneurial projects and manages all interactions with the entrepreneur's environment (Hernandez, 2001 and Fayolle, 2003). The entrepreneur is still considered to be a visionary, able to seize the opportunities and needs of the market, adapt the strategy of their project and involve stakeholders in them (Gomez, 1996; Bares and Cornolti, 2005). Baum et al. (1998) emphasized the importance of entrepreneur vision to anticipate risks and overcome the implementation phase of the project. On the other hand, vision identifies uncertainties surrounding the project and subsequently ensures setting clear and operational objectives to capture the confidence of the various stakeholders (Filion, 1991; Bryant, 2004; Schmitt et al., 2008). To McClelland (1961), a strategic vision increases entrepreneurial motivation and results in effective project implementation. Levy-Tadjine (2012) strongly supports the hypothesis that only the strategic vision ensures the completion of entrepreneurial projects. It should be a mandatory part of the entrepreneurial process. Therefore, we formulate the following hypothesis:

H4: Mobilizing entrepreneurial leadership through vision affects the implementation of key projects.

The answer to our problem thus requires checking four basic hypotheses (H1, H2, H3 and H4). Our concern is to identify the causes of the non-completion of promising projects by young entrepreneurs. It seems that lack of capital and reluctance of banks to finance impedes the completion of projects. However, good governance and a visionary spirit by project promoters help to overcome barriers to the implementation of projects.

\section{The Empirical Validation}

Tunisia was found struggling with an economic and social crisis, where youth unemployment is increasingly growing. According to the Ministry of Vocational Training and Employment, the number of job seekers has increased considerably since the number of the unemployed amounted to more than 628,400 of which nearly 218,200 are young graduates totalling a rate of $31.6 \%$. As a remedy, entrepreneurship is presented as a means by which to mitigate this phenomenon and have access to employment as stated by Le Van-Lemesle (1988). However, still the result of the entrepreneurial process and the projects remain the main challenges to overcome. The answer to our research problem therefore needs an appropriate methodology Martinet (1990). According to Wacheux (1996), the choice of a qualitative methodology minimizes uncertainties regarding research positioning. Thanks to exploration, the researcher can:

$>$ Structure theoretical concepts of different theoretical and disciplinary fields;

$>$ Propose new hypotheses, a theory or model;

$>$ Produce new knowledge without recourse to prior concepts.

Moreover, as Camerer (1985) suggests "The research process would begin with the completion of exploratory studies, then continue with designing more "solid" quantitative experiments and investigations".

In fact, virtually there is no academic research on the non-completion of entrepreneurial projects which led us to conduct an exploratory study that will ensure the inclusion of all possible hypotheses (Evrard et al., 1997), to collect field information from a representative sample which is defined according to Thietart (2003) by "The elements on which data will be collected" and to better identify problems and causes of the 
non-completion of promising projects by young entrepreneurs in Tunisia . This study is based on a qualitative survey of semi-structured 30-minute interviews. It is made with 63 project entrepreneurs who were housed in business incubators, centres and spaces in the regions of Kairouan, Sousse, Monastir, Ksar Hellal, Mahdia and Bizerta. The first section will be devoted to a one-dimensional analysis that would allow us to describe our sample. The second section will be dedicated to the multivariate analysis using a Principal Components Analysis.

\section{Results}

The Univariate analysis: To describe our sample we used a univariate analysis that identified the following results:

Respondents had an average age of 29. The younger people were aged 23 while the oldest was 52 years. We can also say that this age is conceivable since most respondents had a work experience that varies between 2 and 4 years. In the Tunisian context, Zidani and Jarboui (2011) found that most entrepreneurs financed by banks and created their own projects are under 40 years. According to Benarous (2004), the age of projects promoters plays an important role during granting credits. $74.6 \%$ of projects promoters had a university education, $22.2 \%$ with high school education and $3.2 \%$ with primary education. We note that $79.4 \%$ of entrepreneurs have degrees, (50 respondents in our sample), against only 13 who did not. Although most project promoters are graduates, their ideas or business plans occurred before pursuing specific training in entrepreneurship and business creation as $52.4 \%$ confirmed this against $47.6 \%$. Moreover, for $39.7 \%$ the idea or project is born following a job or an internship, $27 \%$ following an involvement with a project during their training, $14,3 \%$ following meetings with entrepreneurs, $11.1 \%$ answered "Other", $6.3 \%$ following an involvement with a project during their previous training and 1.6\% following a stay abroad.

For the industry where projects promoters consider establishing their businesses, we note that the percentage of dominant responses focus on the "various industries" item, with a rate of $17.5 \%$, next the "industry related services" with $15.9 \%$, "textile and clothing industries" with $14.3 \%$, "mechanical and electrical industries" with $12.7 \%$, "miscellaneous services" with $11.1 \%$, "food industry" with $9.5 \%$ and finally "new technologies, building materials, ceramics and glass, leather and footwear industry and chemical industry" with $4.8 \%$ for each sector. Most potentially created businesses are micro-enterprises (less than 6 employees) accounting for $52.4 \%$ of the businesses. Second are small businesses (6-49 employees) that account for 46\%, then third small and medium enterprises (50-199 employees) with $1.6 \%$. In terms of funding, $46 \%$ of entrepreneurs have not had recourse to venture capital companies they do not even know; $36.5 \%$ have difficulty attracting venture capitalists, but only $17.5 \%$ were able to convince them to fund their projects. This type of financing may have many benefits for project entrepreneurs as indicated by Black and Gilson (1998) through their studies on venture capital companies in the United States. They showed that this type of financing enables us to offer competitive advantages. For Popova and Roosenboom (2013), venture capitalists in Germany and Japan have the advantage of transferring control to the project. This is also justified by the low participation in financing capital since only $1.6 \%$ of entrepreneurs have resorted to institutional investors, $7.9 \%$ to managers and $27 \%$ to their families.

With reference to these results, we find that most projects rely solely on their personal contributions that are generally limited and on family resources, which confirms the hypothesis of Bates (1997) who states that the initial capital of projects promoters comes from family wealth. Thus, Mezhoudi (2001) emphasizes the role of the family in the entrepreneurial process in Tunisia. Moreover, through their studies Aldrich and Fiol (1994) found that interpersonal relationships may overcome difficulties of implementing projects. These results seem to be obvious as the project entrepreneur cannot accomplish alone the business creation process. Since they do not have other capital funding sources, they sometimes ignore the existence of other means of financing. This minimizes their chances of bank loans and compromises their projects. Project entrepreneurs were also asked about the existence of other obstacles which hinder the completion of their projects. This question generated the following results:

$>$ Lack of equipment and manufacturing tools;

$>$ The lack of sophisticated and comfortable working space;

$>$ Lack of a relationships network;

$>$ Difficulty in obtaining administrative clearances;

$>$ The non-valuation of the opportunity; 
$>$ Failure to develop a business plan.

The idea of effectively complete business projects is also strong to 49 , or $77.7 \%$ of respondents. As for the $17.5 \%$ of project promoters, they do not even want to complete it. The remaining $4.8 \%$ believe they will complete it later.

The Multivariate analysis (the Principal Component Analysis): First, and before starting our analysis, we need to ensure the reliability (internal consistency) of our scale by examining its homogeneity, which will reduce random error. According to Evrard and al (1997) and Igalens and Roussel (1998), estimating reliability is a necessary but not a sufficient condition for validity. Reliability is often checked through the calculation of Cronbach's alpha. It mainly works with ordinal, ratio or interval scales. However, Evrard et al. (1997) and Igalens and Roussel (1998) noted that some non-interval scales, ordinal or Likert-type scales are most often treated as metric scales. Furthermore, to ensure the reliability of the results, the interview statements were analyzed by ensuring the adequate coefficient of Cronbach's alpha (Nunnally, 1972). This allows us to test internal consistency through calculating correlation of each item of the scale with at least one other item. Thus, these items measure precisely and uniquely the analyzed construct. In general, the alpha coefficient estimates variance of the total score of the common factors of the specific items of the tested scale. However, respecting the critical thresholds remains the only concern. According to Igalens and Roussel (1998), the choice of a threshold "plays a vital role in the purification process of a questionnaire. A threshold of $0.50,0.60$ or 0.70 can significantly change the condensation process, that is to say, the number of items to eliminate". For Evrard and al (1997, p. 292) this threshold depends on the nature of the study. "In an exploratory study, alpha is acceptable if it is between 0.6 and 0.8 ".

Referring to our case study, we find that the overall alpha coefficient is equal to 0.722 , a value which corresponds to the standard used by Evrard et al. (1997). The scale thus has a good internal consistency. Second, we conducted a Principal Component Analysis (PCA) as the data relate to a questionnaire analyzing the problems and factors of the non-completion of projects of project promoters in Tunisia. The questionnaire consists of 12 items to which the 63 project promoters answered "Yes", "No" or "No Answer". They were asked about their ability to manage, their visions as managers, their skills and the obstacles to financing their projects. In fact, a Principal Component Analysis allows assembling some variables into factors, making up in their turn a model explaining the factors of the non-completion of projects among entrepreneurs. Its principle is to reduce the original variables into a smaller number of factors that summarize better information. Eventually, the factors will be ranked in an ascending order. The basis of the factoring process is to find successively a first factor that better summarizes the information contained in the original matrix, then a second, independently of the first, that summaries the best residual information and so on, until reaching a number of factorial axes. Each factor or axis is associated with an eigenvalue, the sum of which is equal to total variance. In our study and for methodological considerations, we have retained only factors with eigenvalues greater than 1 .

On the other hand, to ensure a good description of the results and to better interpret them, the Principal Component Analysis was subjected to a varimax rotation since it seems the most robust conceptually. Its principle is to maximize the sum of the variances of the squared loadings for each factor, i.e. it reduces the number of items that have strong contributions for each column (axis) to simplify and reduce factors. Therefore, rotation helps us to interpret the factors by increasing the value of the correlation coefficients of some items with new factors which improves their performance. Subsequently, we measured sampling adequacy through the KMO index. This latter gives an overall idea about the quality of inter-correlations of items. It generally varies between 0 and 1 and enriches the examination of the correlation matrix for additional information. As it identifies the number of components (factors) as suggested by Evrard and al (1997), "The number of components can be determined using the Kaiser criterion. Indeed, PCA explains in few variables the possible maximum variance. This decision rule is considered the most used".

Table 1: KMO index and Bartlett's test

\begin{tabular}{lll}
\hline Kaiser-Meyer-Olkin sampling adequacy measure. &, 739 \\
Bartlett's Sphericity Test & Approximated Chi-square & 131,586 \\
& Df & 66 \\
& Bartlett significance &, 000 \\
\hline
\end{tabular}


The Principal Components Analysis of our data therefore identifies satisfactory indicators of validity and an overall sample accuracy. KMO is 0.739 ( $>0.7)$, which is quite satisfactory for indicating a good capacity of data to be factored. Moreover, we run Bartlett's sphericity test to identify significant correlations between items. This test is a chi-square test and its interpretation is based on the value of the chi-square / degrees of freedom ratio. It is significant at 0.000 which confirms the good representation of the Principal Component Analysis and ensures that the studied items are adequately represented. Hence, the preliminary analysis results revealed a factor structure with four factors. This solution reconstructs a high variance of $57.634 \%$ which is also satisfactory. Our scale is reliable and valid.

Factor Selection : We then need to select the number of factors to extract. To this end, we examine total variance explained. Looking at the second column, we find that four factors have an eigenvalue higher than 1 . The first factor alone explains $27.346 \%$ of total variance of the 12 items. Pooled together, the four factors explain $57.634 \%$ of variance. Factors 5-12 are not considered because they do not explain enough variance. However, we want to be certain that we select the correct number of factors to extract. Therefore, we looked at the graph of the absolute values and examined where Cattell's cut point breaks. We see a change after the third factor. We retain only three factors for analysis, since this criterion is more stringent than that of the eigenvalues. Because we used only three factors, we repeated the analysis by specifying that we wanted to keep the same number of factor in the extraction dialog box. We can again look at the matrix of total variance explained. We can see that our three factors explain $49.136 \%$ of total variance.

Factor Interpretation : Thanks to the examination of the rotated component matrix, we were able to identify the optimal combination of variables that are mostly associated with the most representative factors and to guarantee a simple factorial representation. To do so we performed a varimax rotation. This technique allowed us to have a good distribution of the variables on the various factors and to increase the gap between correlations. Through this procedure, we found at least three variables that load on each factor. They will be retained to construct scales. We also note that some variables remarkably load on more than one factor. This means they do not position themselves properly on a single factor and it would be better to remove them. From these results we can make some conclusions. First, interviewed project promoters had funding problems. Variables (Difficulties in obtaining bank financing "0.838" share in funding capital "0.735", and financial obstacles "0.573") indicate that they consider the financial factor as the main obstacle to the implementation of their projects. This confirms the results of the study of Rajan and Zingales (1998) on the creation of new businesses where they showed that it depended on external funding. Jaramillo and al (1996) also share the same findings that project promoters are more constrained in their access to external financing, since they are unfamiliar with lenders and there is no trust relationship with them. Ziane (2004) also showed that the participation of banks in financing increases the chances of project implementation. Moreover, this result is consistent with that of Hubbard (1998) who showed that lack of capital causes an inability to obtain external financing.

At the same time, they feel they have no problems with managing their potential business. Variables ability to estimate needs " 0,762 " and the predisposition of skills needed to create a business" 0.716 ", illustrate that respondents believe they have the ability to estimate their financial needs, as they have the business skills and competencies needed to create a business. In summary, we believe that entrepreneurs' ability to manage their own businesses is strong and is exciting for our respondents. Moreover, this result is consistent with that of Fama (1980) who showed that governance ensures the implementation of projects and enhances the potential for value creation. Similarly, several studies such as those of Hernandez (2001) and Dechamp et al. (2005) showed that good governance plays a very important role in completing projects. The study of Bourguiba and Schmitt (2008) has shown that intuition alone significantly reduces the chances of project implementation and good governance will be necessary for projects completion.

Finally, vision seems to be a source of support to encourage aspiring entrepreneurs to develop their businesses. The variable decision-making " 0.817 " proves they have the ability to make decisions even if they lack information. This result agrees with that of Dechamp et al. (2005) who concluded that the intuitive entrepreneur always needs strategic vision to ensure the accomplishment of the project. These results therefore indicate that project entrepreneurs are known by their willingness to do and their ability to master various situations. In this regard, Hernandez (2001) proved that vision of entrepreneurs can make the difference. Similarly, Levy-Tadjine (2012), studying several Lebanese entrepreneurs, 
showed that strategic vision is often internalized. Moreover, this result confirms that of Fama (1980) who assumes that vision is a prerequisite for the implementation of projects.

\section{Conclusion}

Our research focused on the identification of problems and factors of the non-completion of business projects by young entrepreneurs in Tunisia. Tracking the intention of creating a company to actual creation depends on certain factors that can promote or inhibit action. We found that there is a virtual absence of academic research on the non-completion of projects. This led us to conduct a qualitative study. In our study, we investigated four main factors that directly affect the entrepreneurial process and play a very important role in the completion of business projects. The results showed that young project entrepreneurs do not dispose of sufficient capital to reassure stakeholders of the business process and create their own businesses. In addition, resources availability and ease of access to finance is the primordial factor behind the non-completion of projects. Most entrepreneurs have access to bank loans for simple classical reasons, namely insolvency, risk-taking level, lack of collateral, etc. However, they trust their cognitive skills and knowledge as graduates $(72.1 \%$ of the project promoters have degrees) to manage well their potential companies by their ability to operate, identify business opportunities, lead, develop a strategy for their companies, control and build good relationships and a favourable climate with the different stakeholders in order to create value. Furthermore, mobilizing entrepreneurial vision by the entrepreneur seems to have no influence on the implementation of business projects. Although it is an important source of competitive advantage, it has not helped to overcome problems and obstacles facing the completion of projects.

\section{References}

Adler, P. S. \& Kwon, S. (2002). Social capital: Prospects for a new concept. Academy of Management Review, 27(1), 17-40.

Alchian, A. A. \& Demsetz, H. (1972). Production, Information Costs, and Economic Organization. American Economic Review, 62(5), 777-795.

Aldrich, H. (1999). Organizations Evolving. Sage Publications, Londres.

Aldrich, H. E. \& Martinez, M. A. (2001). Many are called, but few are chosen: An evolutionary perspective for the study of entrepreneurship. Entrepreneurship Theory and Practice, 25(4), 41-56.

Aldrich, H. \& Fiol, C. M. (1994). Fools rush in? The institutional context of industry creation. Academy of Management Review, 19(4), 645-671.

Aghion, P. H., Dewatripont, M., Hoxby, C., Mas-Colell, A. \& Sapir, A. (2007). Why Reform Europe's Universities? Bruegel Policy Brief.

Analoui, F. \& Karami, A. (2003). Strategic Management in Small and Medium Sized Industries. Thomson, UK.

Baldwin, J. \& Johnson, J. (1996). Human Capital Development and Innovation : A Sectoral Policies Analysis in P. Howitt (ed.), The implications of Knowledge-Based Growth for Micro-Economic, Calgary : Calgary University Press.

Bates T. (1991). Commercial Bank Financing of White- and Black-Owned Small Business Start-ups. Quarterly Review of Economics and Business, 31(1), 64-80.

Bates, T. (1997). Financing Small Business Creation: the Case of Chinese and Korean Immigrant Entrepreneurs. Journal of Business Venturing, 12(2), 109-124.

Baum, I. R., Locke, E. A. \& Kirkpatrick, S. A. (1998). A longitudinal study of the relation of vision and vision communication to venture growth in entrepreneurial firms. Journal of Applied Psychology, 83, 43- 54

Bares, F. \& Cornolti, C. (2005). Investigation des conditions de succès au démarrage de deux spin-offs universitaires à partir de la théorie des conventions. Revue de l'Entrepreneuriat, 4(1).

Bayad, M., Boughattas, Y. \& Schmitt, C. (2006). Le métier de l'entrepreneur : le processus d'acquisition de compétences. Actes du $8^{\mathrm{e}}$ Congrès international francophone en entrepreneuriat et PME, Fribourg.

Benarous, M. (2004). La Banque Tunisienne de Solidarité : solidaire pas caritative. Laboratoire d'analyse et de perspectives économiques (LAPE).

Begley, T. M. \& Boyd, D. P. (1987). Psychological characteristics associated with performance in entrepreneurial firms and smaller businesses. Journal of Business Venturing, 2, 79-93.

Berle, A. A. \& Means, G. C. (1932). The Modern Corporation and Private Property. MacMillan: NewYork. 
Black, B. \& Gilson, R. (1998). Venture Capital and the Structure of Capital Markets: Banks vs Stock Markets. Journal of Financial Economics, 47, 243-277.

Botzung, M. (1996). Dispositifs d'appui et financement de la petite entreprise. Tiers Monde, 145, 135-152.

Bourguiba, M. \& Schmitt, C. (2008). Aider l'entrepreneur à concevoir une vision. In C. (Ed), Regards sur l'évolution des pratiques entrepreneuriales, Presses Universitaires du Québec.

Bryant, T. A. (2004). Entrepreneurship». In G. R. Goethals, G. J. Sorensen, \& J. M. Burns (Eds.). Encyclopaedia of Leadership, 1, 442 - 448. Thousand Oaks, CA7 Sage.

Camerer, C. (1985). Redirecting Research in Business Policy and Strategy. Strategic Management Journal, 6, 1-15.

Casson, M. C. (1995). Entrepreneurship and Business Culture. Aldershot: Edward. Elgar

Charreaux, G. (2002). Le gouvernement des entreprises. In J. Allouche (coord.), Encyclopédie des ressources humaines, Economica.

Charreaux , G. (2000). Le conseil d'administration dans les théories de la gouvernance. Revue du Financier, 127, 8-17.

Charreaux, G. (2002 a). Variation sur le thème 'A la recherche de nouvelles fondations pour la finance et la gouvernance d'entreprise. Finance Contrôle Stratégie, 5(3), 5-68.

Charreaux, G. (2002b). L'actionnaire comme apporteur de ressources cognitives. Revue Française de Gestion, 28(141), novembre-décembre, nº spécial, p 77-107.

Callon, M. (1989). La science et ses réseaux. Genèse et circulation des faits scientifiques. Paris, La Découverte, p.214.

Cherif, M. (1999). Asymétrie d'information et financement des PME innovantes par le capitalrisque. Revue d'économie financière, 54(54), 163-178.

Cope, J. (2011). Entrepreneurial learning from failure: An interpretative phenomenological analysis. Journal of Business Venturing, 26, 604-623.

Cope, J., Cave, F. \& Eccles, S. (2004). Attitudes of venture capital investors to entrepreneurs with previous business failure. Venture Capital: An International Journal of Entrepreneurial Finance, 6 (2/3), 147-172.

Couteret, P., St-Jean, E. \& Audet, J. (2006). Le mentorat: condition de réussite de ce mode d'accompagnement de l'entrepreneur. Communication présentée 23e Colloque annuel du Conseil Canadien des PME et de l'Entrepreneuriat, Trois-Rivières, Québec. P. 28-30.

Cooper, A. C., Gimeno-Gascon, F. J. \& Woo, C. Y. (1994). Initial Human and Financial Capital as Predictors of New Venture Performance. Journal of Business Venturing, 9(5), 371-395.

Dechamp, G., Goy, H., Grimand, A., Levy, T. \& De Vaujany, F. X. (2005). Gestion stratégique et perspective appropriative: comparaison des modes endogènes et exogènes. In F.X. de Vaujany (Ed), De la conception à l'usage ; Vers un Management de l'appropriation des outils de Gestion, EMS, p. 3579.

Dunn, T. \& Douglas, H. E. (2000). Financial Capital, Human Capital, and the Transition to SelfEmployment: Evidence from Intergenerational Links. Journal of Labor Economics, 18(2), 282305.

Evans, D. S. \& Jovanovic, B. (1989). An estimated model of entrepreneurial choice under liquidity constraints. Journal of Political Economy, 97(4), 808-827.

Evrard, Y., Pras, B., Roux, E., Choffray, J. M., Dussaix, A. M. \& Market, L. (1997). Etudes et Recherches en Marketing - Fondements, Méthodes, 2 ème Edition, Edition Nathan, Paris.

Fairlie, R. W. \& Robb, A. (2008). Race and entrepreneurial success: Black, Asian, and white owned businesses in the United States. Cambridge, MA: MIT Press.

Fama, E. F. (1980). Agency Problems and the Theory of the Firm. Journal of Political Economy, 88(2), 288307.

Fama, E. \& Jensen, M. (1983). Separation of Ownership and Control. Journal of Law and Economics, 27, 301-326.

Fazzari, F., Hubbard, R. \& Petersen, B. (1988). Financing Constraints and Corporate Investment. Brookings Papers on Economic Activity, 1(2).

Fayolle, A. (2003). Le Métier de Créateur d'Entreprise, Editions d'Organisation.

Fayolle, A. \& Nakara, W. (2010). Création par nécessité et précarité : la face cachée de l'entrepreneuriat, 2ème Conférence de la Fondation Nationale pour l'Enseignement et la Gestion des Entreprises (FNEGE), EGM, Paris, France.

Filion, L. J. (1991). Vision et Relations : Clefs du Succès de l'Entrepreneur, Montréal, Les Editions de l'Entrepreneur.

Forker, J. (1992). Corporate Governance and Disclosure quality. Accounting and Business Research, 22(86), 111-124. 
Gartner, W. B. (1985). A Conceptual Framework for Describing the Phenomenon of New Venture Creation. Academy of Management Review, 10(4), 696-706.

Gomez, P. Y. (1996). Le Gouvernement d'entreprise. Inter Editions

Greenberger, D. B. \& Sexton, D. L. (1988). An Interactive Model of New Venture Creation. Journal of Small Business Management, 26(3), 1-7.

Gupta, A., Bo-Chiuan, S. \& Zhiping, W. (2004). An Empirical Study of Consumer Switching from Traditional to Electronic Channels: A Purchase-Decision Process Perspective. International Journal of Electronic Commerce, 8(3), 131-61.

Hatala, J. P. (2005). Identifying Barriers to Self-employment: The Development and Validation of the Barriers to Entrepreneurship Success Tool. Performance Improvement Quarterly, 18(4), 50-70.

Hellmann, T. (2000). Entrepreneurship and the Process of Obtaining Resource Commitments, Research Papers, Stanford University, Graduate School of Business.

Hernandez, E. M. (1999). Le processus entrepreneurial. Vers un modèle stratégique d'entrepreneuriat. Paris, l'Harmattan.

Hernandez, E. M. (2001). Entrepreneuriat : Approche Théorique. L'Harmattan.

Hout, M. \& Rosen, H. S. (2000). Self-employment, family background, and race. Journal of Human Resources, 35, 670-692.

Hubbard, R. G. (1998). Capital-market imperfections and investment. Journal of Economic Literature, 36, 193-225.

Igalens, J. \& Roussel, P. (1998). Méthodes de Recherche en Gestion des Ressources Humaines. Economica, Paris.

Jaramillo, F., Schiantarelli, F. \& Weiss, A. (1996). Capital market imperfections before and after financial liberalisation: An Euler equation approach to panel data for Ecuadorian firms. Journal of Development Economics, 51, 367-386.

Jensen, M. \& Meckling, W. (1976). Theory of the firm: Managerial behaviour, agency costs and Ownership Structure. Journal of Financial Economics, 3(2).

Julien, P. A. \& Marchesnay, M. (1988). La Petite Entreprise. Paris, Vuibert.

Kirzner, I. M. (1997). Entrepreneurial discovery and the competitive market process: An Austrian approach. Journal of Economic Literature, 35, 60-85.

Klein, P. G. (1999). Entrepreneurship and corporate governance. The Quarterly Journal of Austrian Economics, 2(2), 19-42.

LAKHAL, F. (2006). Les mécanismes de gouvernement d'entreprise et la publication volontaire des résultats en France. Comptabilité Contrôle Audit, 12(2), 69-92.

Learned, K. E. (1992). What happened before the organization? A model of organization formation. Entrepreneurship Theory \& Practice, 17, 39-48.

Levy-Tadjine, T. (2012). Entrepreneuriat et vision stratégiqu: Descente au pays des borgnes et des myopes en compagnie de David Galula». Colloque International Francophone de recherches en Entrepreneuriat et sur la PME (CIFEPME), Brest : France

Lichtenstein, B. B., Uh-Bien, M., Marion, R., Seers, A., Orton, J. D. \& Schreiber, C. (2006). Complexity leadership theory: An interactive perspective on leading in complex adaptive systems. Emergence: Complexity and Organization, 8(4), 2-12.

Leftwich, R. W., Watts, R. L. \& Zimmerman, J. L. (1981). Voluntary corporate disclosure: The case of interim reporting. Journal of Accounting Research, 19, 50-77.

Le Van-Lemesle, L. (1988). L'Eternel Retour du Nouvel Entrepreneur. Revue Française de Gestion, 3, 134 140.

Lofstrom, M., Bates, T. \& Parker, S. C. (2013). Why are some people more likely to become smallbusinesses owners than others: Entrepreneurship entry and industry-specific barriers. Journal of Business Venturing, 5(4).

Mantere, S., Aula, P., Vaara, E. \& Schildt, H. (2013). Attributions narratives de responsabilité dans entrepreneurial échec. Journal of Business Venturing, 28(4), 459-473.

Martinet, A. C. (1990). Epistémologie et sciences de gestion. Economica.

Michael, S. C. \& Combs, J. G. (2008). Entrepreneurial Failure: The Case of Franchisees. Journal of Small Business Management, 46(1), 73-90.

Mckenzie, B. (2008). A Hermeneutical Approach to Understanding Entrepreneurial Failure. Academy of Entrepreneurship Journal, 14(1/2).

Mezhoudi, L. (2001). L'essaimage d'entreprises et l'appropriation de la technologie. Thèse de doctorat sous la direction de Zghal R., ISG de Tunis.

Mohnen, P. \& Rosa, J. (2001). Les obstacles à l'innovation dans les industries de services au Canada. L'Actualité économique, 77(2), 231-254. 
Michael, S. C. \& Combs, J. G. (2008). Entrepreneurial Failure: The Case of Franchisees. Journal of Small Business Management, 46(1), 73.

Mantere, S., Aula, P., Schildt, H. \& Vaara, E. (2013). Attributions narratives de l'échec entrepreneurial. Journal of Business Venturing, 28(4), 459-473.

McClelland, D. C. (1961). The achieving society. The Free Press, New York.

Mises, L. V. (1949). Human action: A treatise on economics. (4th revised ed.). San Francisco: Fox \& Wilkes.

Morin E. (2001). Le monde comme notion sociologique. Dans Daniel MERCURE (dir.), Une sociétémonde ? Les dynamiques sociales de la mondialisation, Sainte-Foy, Les Presses de l'Université Laval, p. 191-197.

Nahapiet, J. \& Ghoshal, S. (1998). Social capital, intellectual capital, and the organizational advantage. Academy of Management Review, 23, 242-266.

Nunnally, J. C. (1972). Educational Measurement and Evaluation. 2ème Edition. New York. McGraw-Hill.

Oliver, C. (1997). Sustainable competitive advantage: combining institutional and resource based views. Strategic Management Journal, 18, 697-713.

Owualah, S. I. (1987). Providing necessary economic infrastructure for small Business. Antsem, p. 10-30.

Popova, A. \& Roosenboom, P. (2013). Venture capital and new business creation. Journal of Banking \& Finance, 37(12), 4695-4710.

Parker, S. C. (2009). The Economics of Entrepreneurship. Cambridge University Press, $1^{\text {sted. }}$

Parker, S. C. \& Van Praag, C. M. (2006). Schooling, capital constraints and entrepreneurial performance: the endogenous triangle. Journal of Business \& Economic, 4(3).

Rajan, R. \& Zingales, L. (1998). Financial Dependence and Growth. American Economic Review, 88(3), 559-86.

Raghuram, G. R. \& Zingales, L. (1998). Financial Dependence and Growth. American Economic Review, 88(3), 559-586.

Rogers, C. R. (1976). Liberté pour apprendre ?. Paris, Dunod.

Rogoff, E. G., Lee, M. S. \& Suh, D. C. (2004). Who Done It? Attributions by Entrepreneurs and Experts of the Factors that Cause and Impede Small Business Success. Journal of Small Business Management, 42(4), 364-376.

Schmitt, C., Gallais, M. \& Bourguiba, M. (2008). Aider l'entrepreneur à concevoir une vision : besoins des entrepreneurs et proposition d'une démarche. Dans SCHMITT C. (dir), Regards sur l'évolution des pratiques entrepreneuriales, Presses de l'Université du Québec, Collection Entrepreneuriat et PME, p. 175-192.

Scott, W. R. (1995). Institutions and Organizations. Thousand Oaks, CA: Sage.

Scott, W. R. \& John, W. M. (1991). The rise of training programs in firms and agencies: An institutional perspective. In Research in Organizational Behavior, 13, 297-326, Barry M. Staw \& L. L. Cummings, ed. Greenwich, CT: JAI Press.

Stewart, W. H. J., Watson, W. E., Carland, J. C. \& Carland, J. W. (1999). A proclivity for entrepreneurship: A comparison of entrepreneurs, small business owners, and corporate managers. Journal of Business Venturing, 14(2), 189-214.

Sharma, P. \& Chrisman, J. J. (1999). Toward a Reconciliation of the Definitional issues in the Field of Corporate Entrepreneurship. Entrepreneurship Theory and Practice, 23(3), 11-28.

Thiétart, R. A. (2003).Méthodes de Recherche en Management, Dunod, 2ème Edition.

Ucbasaran, D., Westhead, P., Wright, M. \& Flores, M. (2010). The nature of entrepreneurial experience, business failure and comparative optimism. Journal of Business Venturing, 25(6), 541-555.

Verstraete, T. (2001). Entrepreneuriat : modélisation du phénomène. Revue de l'Entrepreneuriat, 1(1).

Wacheux, F. (1996). Méthodes qualitatives et recherche en gestion. Ed Economica Gestion.

Watkins, D. (1976). Entry into independent entrepreneurship: toward a model of the business initiation process, working paper series, Manchester Business School and Center for Business Research.

Willerding, I. A. V., Prado, M. L. \& Lapolli, E. M. (2012). A trilogy of entrepreneurship: performance, capacity and competence as a factor of success for micro and small enterprises. IEEE Latin America Transactions, 10(5).

Witt, U. (1998a).Imagination and leadership: The neglected dimension of an evolutionary theory of the firm. Journal of Economic Behavior and Organization, 35, 161-177.

Witt ,U. (1998b). Do entrepreneurs need firms? Review of Austrian Economics, 11, 99-109.

Yiu, D. W. \& Lau, C. M. (2008). Corporate entrepreneurship as resource capital configuration in emerging market firms. Entrepreneurship: Theory and Practice, 32(1), 37-57.

Ziana, Y. (2004). La structure d'endettement des PME françaises : une étude sur données de panel. Revue internationale $P M E, 1(1)$.

Zidani, H. \& Jarboui, A. (2011). L'incidence des Facteurs socio-economiques sur le Financement des microprojets par LA Banque Tunisienne de Solidarité: Cas de la Tunisie. Revue Libanaise de Gestion et d'Economie, 4(6), 158-181. 